effect of this change on the various reactions taking place.

Some brief references were also made to the importance of finding a really accurate method for measuring the true permeability rates of extremely thin membranes. Theoretical investigations in this field have already been made by Prof. A. V. Hill, and Dr. F. J. W. Roughton indicated how the stream. ing method could be made applicable to blood cells, thus permitting an examination of the true rates of ingress and egress both of non-electrolytes and of jons.

Eric K. Rideal.

\title{
Water Supply
}

$I^{\mathrm{T}}$ $\mathrm{T}$ is natural and appropriate that the paramount topic of the drought should find a prominent place in the presidential address of $\mathrm{Mr}$. Councillor Thomas Paris at the annual meeting of the British Waterworks Association (Incorp.) at Edinburgh on June 27. Much of what he had to say respecting the pernicious effects of a shortage of water has been a matter of common experience, but he made the pertinent observation that many of the failures in supply can be traced to procrastination and lack of courage in promoting water schemes. This was more particularly in reference to rural areas where, he emphasised, "the importance of an abundant supply of wholesome water is hardly to be over-estimated" since insufficient or impure water in those areas has wide-reaching effects on public health through milk and foodstuffs produced for general consumption. He alluded to the frequent lack of storage facilities and urged all councils, regional, urban and rural, to take action in the direction of increasing their storage and, where necessary, constructing new waterworks. Another of his points was river pollution, which, he contended, in the national interest must cease. He instanced the case of Edinburgh, where a few years ago there was a turbid stream flowing through the city, "offensive to eye and nostril". The action taken by civic authority has resulted in the transformation of a public nuisance and a menace to health into a "fished water". $\mathrm{He}$ is opposed to the formation of a national water grid, alleging that the argument for such a grid, so far as Scotland is concerned, is without foundation. The question in his view is not one of water shortage, but rather of storage and distribution.

Among the papers contributed to the Conference was one of a particularly timely character on the "Consumption, Misuse and Waste of Water". Mr. John Bowman, the author of the paper, directed attention to the striking difference in the quantities of water supplied per head per day by various authorities. He gave a list of 114 authorities in
England, each supplying a population of more than 50,000 , in which the consumption ranged from 13.00 to 73.45 gallons per head per day. Another list showed that among 27 water authorities in Scotland, the consumption ranged from 34 to 92 gallons per head per day. Commenting on the subject of undue consumption, which might be defined as the use of more water than is necessary, he said : "a person living in a country where. water is scarce may find it possible to perform all his ablutions with one gallon of water per day, and half as much again for culinary and drinking purposes. In civilised countries it would appear that, at least, from 4 to 6 gallons per head must be allowed, where there is no water used for baths or water-closets". Where water is used in addition for the supply of water-closets, it would appear that the lowest figure is about 10 gallons per head. Much depends on the class of property. Houses of the residential class have a higher per capita consumption than small tenements.

Mr. Bowman went on to ask the question: What is to be regarded as the future requirements for ordinary domestic consumption? He gave it as his opinion that within the next twenty years at least 20 gallons per head per day would have to be provided for the increased use of baths. The requirements per head per day would then be in the region of 50 gallons. Perhaps forty years from now a consumption of 80 gallons might be considered possible. In American towns 80 gallons per head is looked upon as a normal consumption. Dealing with the question of waste, which he attributed largely to defective fittings, he stated that a good deal of it might be eliminated by the installation of heavy service piping and good fittings. Useful work, he thought, might be done in educating the householder in the avoidance of waste due to faulty fittings and in getting him to see that taps were left properly turned off and to use water without undue consumption.

\section{Fish Preservation in Trawlers}

$\mathrm{W}$ ITH the introduction of steam-driven vessels - somewhere about the year 1870-the great development of the present long-distance, deep-sea trawling industry became possible. But the industry's present greatness is not due to steam alone. Had not the practice of stowing the catch in crushed ice been also introduced about the same time, the bringing back of fish in a saleable condition from far distant grounds would have been impossible even for large and powerful steamers unaffected by the vagaries of wind-propulsion.

In recent years many experiments have been made in an endeavour to evolve and perfect a more satisfactory method of preserving fish at sea. In spite of every effort towards improvement, however, the stowage of trawled fish in crushed ice is still the general practice, notwithstanding its very serious limitations.

The preservative effect of crushed ice is two-fold. By lowering the temperature of the fish tissues, changes due to autolysis are slowed down. This lowering of temperature also slows down the rates at which the bacteria of decay grow and multiply; but stowage in crushed ice alone cannot inhibit their activities completely.

Bacteria of decay are present on the fish when caught, but only in negligible numbers. As at present handled on board ship after capture, however, the fish become very heavily infected with these organisms. As a result of this severe infection, storage 